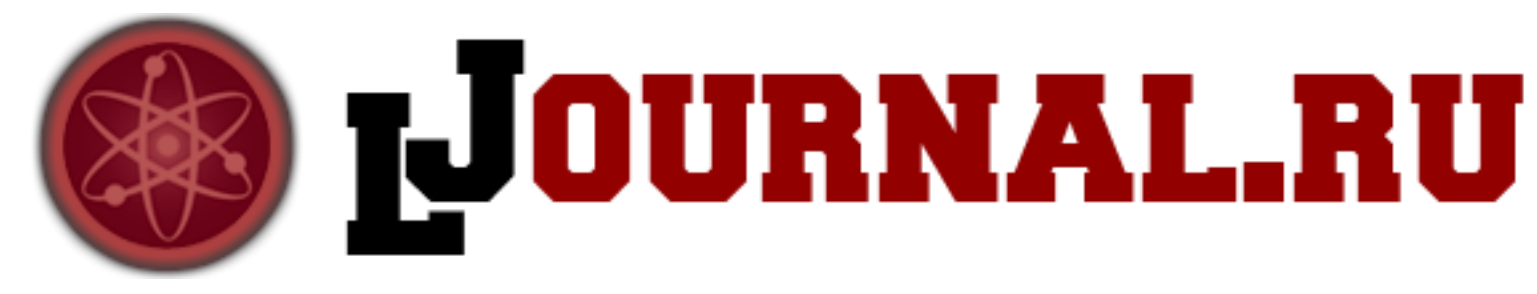

\author{
Волошин Д. А., Трандофилов А. А. \\ ФГБОУ ВО «Армавирский государственный педагогический \\ университет» \\ Армавир, Россия
}

doi: 10.18411/1j2016-1-04

\title{
О нектороых элементах «византийской симфонии» в практике церковно- государственных отношений современности
}

Тема взаимоотношений Церкви и Государства в мировой исторической, религиозной и философской мысли всегда занимала отдельное, особенное место в силу собственной значимости и фундаментальности затрагиваемых проблем. В различные исторические эпохи роль того или иного института в жизни разных обществ то возрастала, то умалялась под прямым воздействием различных внешних и внутренних факторов. В настоящее время роль «религиозного фактора» порой достигает своих пиковых значений, этот фактор становится конститутивным для исторического развития целых регионов.

То, что государственные и религиозные институты и в прошлом, и в настоящем тесно коррелируют друг с другом, не является новостью для исследователей. Современные исследователи [1] склонны из всего многообразия вариантов сосуществования государства и церковной организации выделять три модели их взаимодействия:

— цезарепапизм (подчинение Церкви государственной власти);

— папоцезаризм (превалирование духовной власти над светской);

— симфония (sumjwnia; consensus), которая предполагает союз церковной и государственной власти. 
Вышеупомянутый союз, к слову, не есть продукт механического соединения, - в основе его «...лежит идея гармонии и согласия властей, сосуществующих, но не сливающихся друг с другом, взаимодействующих, но не стремящихся к подчинению друг друга» [2]. Куда меньше единства в вопросах, связанных с общеисторической оценкой подобного рода практик или в том, что касается актуализации их исторического опыта. Когда речь заходит о парадигме взаимодействия церкви и государственности, исторический пример Византии живо напоминает о себе самым естественным образом, - ибо является ярким примером тысячелетнего (и, надо признать, относительно гармоничного) взаимодействия Церкви и Государства. Пожалуй, только «Византия может похвастаться тем, что нигде вопрос о союзе церкви и государства не был решён более удачно» [3]. Данное столь удачно реализованное Византией историческое

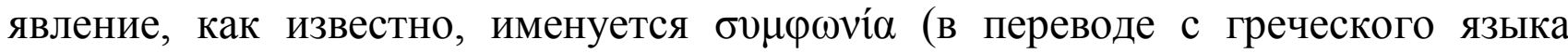
буквально означает «согласие»). То есть византийская «симфония», также именуемая «симфонией властей», представляет из себя гармоничное сочетание церкви и государства в общественной жизни, светского и духовного начал [4].

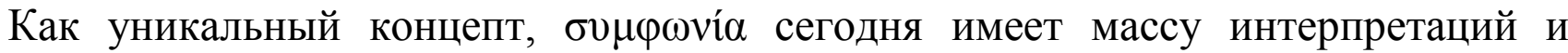
наборов сущностных характеристик; авторство же самой теории относят к византийскому императору Юстиниану I, в чье правление империя достигла наибольшего могущества и величия. Контроль над огромным количеством людей, разных слоев и категорий, живших на обширных территориях, требовал наличия духовных скреп, определенного конструкта прогнозируемых жизненных практик. Сам Юстиниан сформулировал эту теорию в 6-й Новелле: «Величайшие блага, дарованные людям высшею благостью Божией, суть

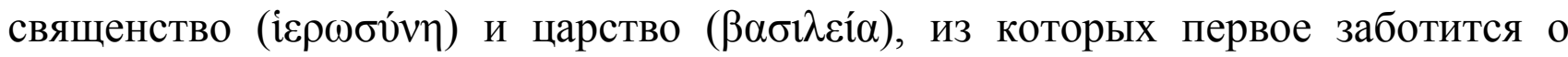
Божественных делах, а второе руководит и заботится о человеческих делах, а оба, исходя из одного и того же источника, составляют украшение человеческой жизни. Поэтому ничто не лежит так на сердце царей, как честь священнослужителей, которые со своей стороны служат им, молясь непрестанно 
за них Богу. И если священство будет во всем благоустроено и угодно Богу, а государственная власть будет по правде управлять вверенным ей государством,

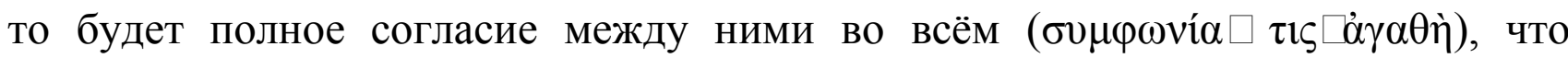
служит на пользу и благо человеческого рода» [5].

Таким образом, в извечной дилемме роли Государства и Церкви четко прописывается разделение их функций - сообразно и в отношении влияния на человека и общество. Так, Церковь отвечает за «душу», Государство - за «тело»

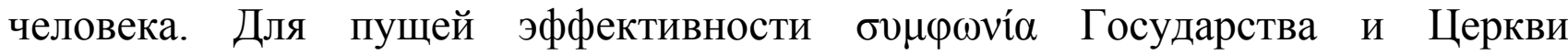
предполагала взаимодействие во всех сферах власти - исполнительной, судебной, законодательной. Для поддержания симфонии со стороны государственной власти требуется сохранение догматов церкви, почитание церковной власти, ее канонов, забота об имущественном благоденствии Церкви. Для поддержания симфонии со стороны церковной власти необходимо распространение среди верующих отношений к Царю как помазаннику Божию, формирование у подданных обязанностей неукоснительного соблюдения законов и полной преданности [6].

Однако в исторической перспективе это правило не было неизменным (подчас даже говорят: это был скорее образ желаемого, бесконечно далекий от реальных практик). Государственная власть время от времени пыталась нарушить этот принцип в свод пользу; не оставались в долгу и первоиерархи... И в этой связи показательны: а) хрестоматийный «византийский» пример (последних десятилетий её существования) - после заключения в 1380-х годах императором Иоанном V Палеологом конкордата с Патриархатом; б) пример из соответствующего (именуемого синодальным) периода отечественной истории, когда власть над иерархией РПЦ имели императоры; а подчинённое положение духовенства усугублялось отсутствием патриаршего возглавления...

Изучение исторического пути развития взаимоотношений Русского государства и Церкви подчас приводит современных исследователей к выделению трех этапов, последовательно сменявших друг друга: 1 этап - 
сосуществование Государства и Церкви в «автономном» (раздельном) формате; 2 этап - сосуществование Государства и Церкви в «симфоническом» формате; 3 этап - сосуществование Государства и Церкви в «цезарепапистском» формате.

Современная ситуация взаимодействия церкви и государства в России предполагает принцип разделения этих институтов, невмешательство в дела друг друга. Однако это не означает вытеснение РПЦ из жизни общества и государства. Наоборот, государство активно взаимодействует с традиционными конфессиями государства и способствует их развитию. Обратимся к Основам социальной концепции Русской Православной Церкви, принятым в 2000 году на Архиерейском Соборе РПЦ, один из тезисов которых гласит: «Во взаимоотношениях между Церковью и государством должно учитываться различие их природ. Церковь основана непосредственно Самим Богом Господом нашим Иисусом Христом; богоустановленность же государственной власти являет себя в историческом процессе опосредованно. Целью Церкви является вечное спасение людей, цель государства заключается в их земном благополучии...» [7]. Итак, в идеале именно равноправие, равная значимость, «неслитное» и «нераздельное» существование церковной и светской власти отличает концепцию симфонии властей от доктрин папоцезаризма и цезарепапизма. Суть ее составляет обоюдное сотрудничество, взаимные поддержка и ответственность, без вторжения одной стороны в сферу исключительной компетенции другой [8].

Признаки теории византийской симфонии (вернее, элементы, отсылающие к ее далекой протомодели) имели и имеют место и в нашей истории. Несут ли они на себе плодотворные плоды социальной стабильности, либо являются реакционной мифологемой, «замиряющей» безо всякой меры население в условиях вопиющей несправедливости социальных отношений - вопрос далеко не праздный. Действительно, гармоничное взаимодействие социальных институтов в значительной части предопределяет успешное развитие общества, особенно когда это касается вопросов духовности; однако не следует забывать 
прописную истину: симфонические отношения - это всегда и непременно взаимозависимость. Взаимозавимость, путь к которой лежит сквозь обретение независимости, - ведем мы речь о Церкви, или о Государстве - неважно. Этот фундаментальный показатель, без которого достичь «неслиянного единства» вряд ли получится. «Византийский урок» построения отношений симфонии, безусловно, сам по себе является колоссальным историческим опытом; в то же время, он полон актуальных для современности предостережений - ибо в практиках повседневности мы все чаще сталкиваемся с издержками, нежели преимуществами подобного рода отношений. Так, в последнее время все чаще говорят о наступающей «клерикальной реакции», о чрезмерной роли церковных институтов в светском государстве, о пагубной практике сращивания церковных и государственных институтов в РФ. Специалистов настораживает проникновение церкви в систему высшего и среднего (!) образования, в вооруженные силы... Уже давно не скрывают религиозные деятели своих претензий на установление обязательных для всех норм морали и правил нравственного (в их понимании) поведения гражданина РФ... Содержание речей церковных иерархов имеет все меньше отличий от выступлений политических деятелей, каждое резонансное событие (как правило, не имеющее ни к церкви, ни к религии никакого отношения) незамедлительно получает свою оценку со стороны людей от Церкви. Вполне явственно проглядывается парадигма, при которой Церковь требует для себя уже не равноправия, но привилегий - и это в светском государстве... Как показывают события последних лет (к христианской религии имеющие лишь опосредованное отношение; но к религиозному радикализму - прямое) угроза тотальной клерикализации вполне может стать еще одним фактором, приближающим наступление эпохи «нового варварства» [9].

Подчас складывается ощущение, что религиозный фактор в реалиях современной РФ играет несколько избыточную роль. По крайней мере, избыточную для государства, чья светскость закреплена на конституционном 
уровне. Ситуация эта, надо полагать, сложилась не в одночасье, - пресловутый идеологический вакуум 90-х, отсутствие национальной идеи и идеологии, отсутствие внятных ответов на вопросы о том, «Кто мы?» и в «Каком обществе мы хотим жить?», «Ради чего мы должны терпеть несправедливость?» - все это сыграло определяющую роль в форсировании религиозного сегмента общественной и духовной жизни. Еще один немаловажный момент - кризис идентичности, так и не преодоленный до сих пор и выражающийся в эсхатологической максиме «Стояния у конца времен» (а потому «Кто, если не мы?» - типичный иррациональный ответ властей для объяснения электоральным массам своих действий - в т.ч. и за пределами наших границ). Кризис идентичности, коим поражено общественное сознание россиян, можно схематично обозначить триадой: «неосмысленное и неоцененное прошлое», «абсолютно непредсказуемое настоящее» и «неочевидное будущее». Другими словами, неопределенные представления об «азиатчине» где-то позади и «псевдоевропеизме» где-то впереди, усугубляемые идеями «особого пути»- в сухом остатке выдают господство старого доброго «православия без христианства», реализующегося скорее в координатах «цезарепапизма», нежели

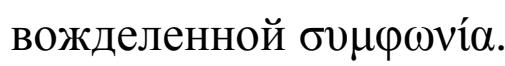




\section{Литература:}

1. См. напр.: Костогрызова Л. Ю. Симфония властей в Византии: опыт взаимодействия государства и церкви // Актуальные проблемы истории, политики и права: сборник научных трудов преподавателей и адъюнктов. - Выпуск 8. - Екатеринбург, 2008. С. 29-35. - С. 29.

2. Николин А. Церковь и государство (история правовых отношений). М.: Изд-во Срет. монастыря, 1997. - 429 с. - С. 15.

3. Тихомиров Л. А. Монархическая государственность. - СПб: Российский имперский союзъ-орденъ, 1992. - 680 с. - С. 151.

4. Император Юстиниан: истоки симфонии Церкви и общества // Татьянин день: православное www-издание МГУ [электронный pecypc]. - URL: http://www.taday.ru (дата обращения: 12.09.2015).

5. Правила Православной Церкви с толкованиями Никодима, епископа Далматинско-Истрийского. - СПб., 1911. - Т. 1. - С. 681-682.

6. Цыганов В. И., Мезина Е. Е. Взаимоотношения государства и церкви: от симфонии властей к цезарепапизму // Вестник Нижегородского университета им. Н. И. Лобачевского. - 2012. - № 6 (1). - С. 245-251. - C. 247.

7. Социальная концепция РПЦ // Патриархия. Ру: официальный сайт Русской Православной церкви [электронный ресурс]. - URL: http://www.patriarchia.ru (дата обращения: 06.09.2015).

8. Цыпин В. Симфония церкви и государства // Православная государственность: 12 писем об империи. Сборник статей под ред. А.М. Величко, М.Б. Смолина. - СПб.: Изд-во юридического института, 2003. 304 c. - C. 15.

9. Подр. см.: Волошин Д. А. Цивилизация. Варваризация. Исторический процесс: Учебное пособие / под ред. С. Л. Дударева. - Армавир: РИО АГПА, 2015. - 100 с. - С. 9. 